\title{
Ormeloxifene inhibits osteoclast differentiation in parallel to downregulating RANKL-induced ROS generation and suppressing the activation of ERK and JNK in murine RAW264.7 cells
}

\author{
Geetika Kharkwal, Vishal Chandra, Iram Fatima and Anila Dwivedi \\ Division of Endocrinology, Central Drug Research Institute (CSIR), Lucknow, Uttar Pradesh 226001, India \\ (Correspondence should be addressed to A Dwivedi; Email: anila.dwivedi@rediffmail.com)
}

\begin{abstract}
Ormeloxifene (Orm), a triphenylethylene compound, has been established as a selective estrogen receptor modulator (SERM) that suppresses the ovariectomy-induced bone resorption in rats. However, the precise mechanism underlying the bone-preserving action of Orm remains unclear. In this study, we evaluated the effect of Orm on osteoclast formation induced by receptor activator of nuclear factor $\kappa B$ ligand (RANKL) in the murine macrophage cell line RAW264.7. We also explored the mechanism of action of Orm by studying the RANKL-induced signaling pathways required for osteoclast differentiation. We found that Orm inhibited osteoclast formation from murine macrophage RAW264.7 cells induced by RANKL in a dose-dependent manner. Orm was able to abolish RANKL-induced reactive oxygen species (ROS) elevation and inhibited the transcriptional activation of two key RANKL-induced transcription factors namely activator protein-1 (AP-1) and NF- $\mathrm{B}$ B through mechanisms involving MAPKs. Activation of two MAPKs, i.e. ERK (MAPK1) and JNK (MAPK8), was alleviated by Orm effectively, which subsequently affected the activation of c-Jun and c-Fos, which are the essential components of the AP-1 transcription complex. Taken together, our results demonstrate that Orm potentially inhibits osteoclastogenesis by inhibiting ROS generation and thereby suppressing the activation of ERK1/2 (MAPK3/MAPK1) and JNK (MAPK8) and transcription factors (NF-KB and AP-1), which subsequently affect the regulation of osteoclastogenesis. These results provide a possible mechanism of action of Orm in regulating osteoclastogenesis, thereby supporting the beneficial bone-protective effects of this compound.
\end{abstract}

Journal of Molecular Endocrinology (2012) 48, 261-270

\section{Introduction}

Estrogen regulates bone metabolism that is controlled by a balance between bone resorption by osteoclasts and bone formation by osteoblasts (Syed \& Khosla 2003). The effects of estrogen on osteoblasts include both direct effects resulting in increased bone formation, and an indirect effect, via an osteoblast-mediated interaction with preosteoclasts and osteoclasts, resulting in decreased bone resorption (Galal et al. 2007). Estrogen exerts its indirect effect through products secreted by osteoblasts that include receptor activator of nuclear factor $\kappa \mathrm{B}$ ligand (RANKL), colony-stimulating factor-1 (CSF1), and osteoprotegerin (OPG), which are important in differentiation and maturation of osteoclasts. In addition, estrogen treatment has been shown to inhibit osteoclast formation from mononuclear hematopoietic stem cells (Jilka et al. 2001) and also affects adhesion and apoptosis of osteoclasts (Saintier et al. 2006, Nakamura et al. 2007). Decrease in reactive oxygen species (ROS) generation (Lean et al. 2003, Maggio et al. 2003) and secretion of pro-inflammatory cytokines interleukin 1 (IL1), IL6, and tumor necrosis factor $\alpha(\mathrm{TNF} \alpha)$ by marrow monocytes (Riggs et al. 2002) add to the beneficial effects of estrogen. It is well documented that TNFrelated activation-induced cytokine (TRANCE; also called RANKL, OPGL, and ODF), originally identified as a member of the TNF family, is expressed by osteoblastic cells and substitutes for stromal cells in osteoclast formation in vitro (Asagiri \& Takayanagi 2007). Binding of RANKL to its signaling receptor RANK leads to recruitment of TNF receptor-associated factor 6 (TRAF6) to the cytoplasmic domain of RANK (Darnay et al. 1999, Kim et al. 2009). This results in the stimulation of various intracellular signaling pathways involving MAPKs (ERK (MAPK1), JNK (MAPK8)/ SAPK, and p38), PI3K/Akt, and NF-кB that are activated in osteoclast precursors and mature osteoclasts (Lee \& Kim 2003, Kim et al. 2005).

Ormeloxifene (Orm), a nonsteroidal selective estrogen receptor modulator (SERM), has been developed as a weekly oral contraceptive pill (Singh 2001). Orm binds to both $\operatorname{ER} \alpha$ and $\operatorname{ER} \beta$ (Blesson et al. 2006). In the 
uterus, it modulates estrogen action by classical estrogen antagonism at corepressor recruitment (Daverey et al. 2009) and via a nonclassical activator protein-1 (AP-1)-mediated mechanism (Awasthi et al. 2007). Orm has also shown anticancer activity in phase II and III clinical trials conducted on terminal cases of breast cancer (Misra et al. 1989). Besides antibreast cancer activity, Orm has been demonstrated to cause the inhibition of estrogen-deficient osteoporosis in rats (Arshad et al. 2004). It induced the apoptosis of osteoclasts via upregulation of TGF $\beta 3$ (TGFB3) expression in rat (Narayana Murthy et al. 2006). However, the precise mechanism by which Orm exerts its tissue-specific estrogen agonistic effect and also the antiosteoclastogenic effect remains unknown. This study was carried out to explore the possible mechanism of osteoclastogenesis inhibition caused by Orm using the murine macrophage cell line RAW264.7. RAW264.7 cells serve as an excellent model of osteoclast differentiation as RANKL treatment induces their differentiation into osteoclast-like tartrate-resistant acid phosphatase (TRAP)-positive cells (Hsu et al. 1999, Collin-Osdoby et al. 2003). Herein, the effects of Orm on RANKL-induced ROS generation, ERK- and JNK-activated c-Jun and c-Fos signaling, during inhibition of osteoclastogenesis and osteoclast differentiation, were studied in RAW264.7 cells (Boyle et al. 2003, Forman et al. 2004).

\section{Materials and methods}

\section{Reagents and antibodies}

All cell culture and SDS-PAGE reagents were purchased from Sigma, unless otherwise stated. Antibodies for c-Jun, phospho-c-Jun, c-Fos, JNK, ERK1/2, phosphoERK1/2, phospho-SAPK, and RANK were purchased from Cell Signaling Technology, Beverly, MA, USA. ER $\alpha$-specific antibody and secondary antibodies were obtained from Santa Cruz Biotechnologies. Reagents for western blot were obtained from GE Healthcare, Bucks, UK. Amaxa kit was procured from Amaxa Biosystems, Gaithersburg, MD, USA. Dichlorofluorescein diacetate (DCFH-DA) was purchased from Invitrogen Life Technologies. $17 \beta$-Estradiol $\left(\mathrm{E}_{2}\right)$ and raloxifene (Ral) were purchased from Sigma. ICI 182780 was purchased from Tocris, Bristol, UK. Orm was synthesized and kindly provided by the medicinal chemists of the Central Drug Research Institute (Tripathi et al. 1997).

\section{Plasmids}

Luciferase reporter plasmids $p A P 1-l u c, p N F-\kappa B-l u c$, and pFR-luc; expression vectors $p F A-c-J u n, p F A-c-F o s$, and pFA-ATF2, and negative control plasmid $p F C-d b d$ were purchased from Stratagene, USA. The expression plasmids used were composed of chimeric genes containing the DNA-binding domain of GAL4 fused to the activation domains of c-Jun, c-Fos, or ATF2. $p R L-S V 40-l u c$ was obtained from Promega, and used as an internal control plasmid during transfection.

\section{Cell culture}

The murine monocytic RAW264.7 cell line was procured from ECACC (Salisbury, UK). The cells were maintained in low-glucose $(1 \mathrm{~g} / 1)$ DMEM, pH $7 \cdot 4$, supplemented with $10 \%$ fetal bovine serum (FBS) and $1 \times$ antibiotic-antimycotic mix. Once the cells became $70 \%$ confluent, they were scraped using the sterile cell scraper and split at a ratio of 1:8. The medium was changed to phenol red-free DMEM containing antibiotics with $10 \%$ charcoal-stripped FBS 3 days before starting the experiment. The cell line was maintained at $37{ }^{\circ} \mathrm{C}$ with $5 \% \mathrm{CO}_{2}$ in humidified incubator.

\section{Characterization and quantitation of osteoclast-like cells}

RAW264.7 cells were cultured in a 96-well plate at a density of 5000 cells/well and treated with RANKL at the beginning of the culture and during a medium change on day 3. Osteoclast formation was assessed by counting the total number of multinucleated cells ( $\geq 3$ nuclei), TRAP-positive cells present per well on day 5 (Collin-Osdoby et al. 2003). Briefly, after incubation, cells were washed with PBS, fixed in $10 \%$ formalin for $10 \mathrm{~min}$, and stained for acid phosphatase in the presence of $0.05 \mathrm{M}$ sodium tartrate (Sigma). Naphthol AS-BI phosphate (Sigma) was used as the substrate. Only TRAP-positive cells, showing a bright pink-colored cytoplasm, were counted by light microscopy.

\section{Cell viability assay}

RAW264.7 cells were plated in a 96-well plate at a cell density of $1 \times 10^{3}$ cells/well and were incubated for $12 \mathrm{~h}$ at $37^{\circ} \mathrm{C}$ and $5 \% \mathrm{CO}_{2}$. After $12 \mathrm{~h}$, the medium was replaced with fresh medium containing $100 \mu \mathrm{M}$ RANKL and the cells were incubated with $\mathrm{E}_{2}(10$ and $100 \mathrm{nM})$, Ral $(100 \mathrm{nM}$ and $1 \mu \mathrm{M})$, or Orm $(100 \mathrm{nM}, 1 \mu \mathrm{M}$, and $10 \mu \mathrm{M})$ for 5 days, with a medium change on the third day. One control group with vehicle (ethanol) alone was also included. After the incubation period was over, MTT was added to the wells at a final concentration of $0.5 \mathrm{mg} / \mathrm{ml}$ and incubated further for $2 \mathrm{~h}$. The medium was then removed and the formazan crystals thus formed were dissolved by adding DMSO and incubated for a further $15 \mathrm{~min}$ at room temperature. Optical density (OD) was measured at $540 \mathrm{~nm}$ in a spectrophotometer. 


\section{ELISA of ERK1/2 (MAPK3/MAPK1) [pTpY185/187] and JNK [pTpY183/185]}

The phosphorylation level of ERK was quantified using ELISA kit (KHO0091; Invitrogen). In brief, RAW264.7 cells were incubated with $\mathrm{E}_{2}(100 \mathrm{nM})$, Ral $(1 \mu \mathrm{M})$, or Orm $(10 \mu \mathrm{M})$ for $24 \mathrm{~h}$ and then stimulated with $200 \mathrm{ng} / \mathrm{ml} \mathrm{RANKL}$ for $30 \mathrm{~min}$. At the end of incubation, cell lysate was prepared by lysing the cells in buffer containing protease and phosphatase inhibitors. ERK/JNK activation was measured using $10 \mathrm{mM}$ Tris, pH 7·4, $100 \mathrm{mM} \mathrm{NaCl}, 1 \mathrm{mM}$ EDTA, $1 \mathrm{mM}$ EGTA, $1 \mathrm{mM}$ $\mathrm{NaF}, 20 \mathrm{mM} \mathrm{Na}_{4} \mathrm{P}_{2} \mathrm{O}_{7}, 2 \mathrm{mM} \mathrm{Na} \mathrm{VO}_{4}, 1 \%$ TritonX-100, $10 \%$ glycerol, $0 \cdot 1 \%$ SDS, and $0.5 \%$ deoxycholate following the manufacturer's instructions. OD was measured with MicroQuant ELISA reader (Biotek, Winooski, VT, USA) at $450 \mathrm{~nm}$. The experiments were performed three times with three replicates in each.

\section{Western blot analysis}

RAW264.7 cells were incubated with $\mathrm{E}_{2}$, Ral, or Orm for $24 \mathrm{~h}$ and were stimulated with $200 \mathrm{ng} / \mathrm{ml}$ RANKL for $30 \mathrm{~min}$. Cell lysate was prepared by lysing the cells in buffer containing $50 \mathrm{mM}$ Tris- $\mathrm{HCl}, 137 \mathrm{mM} \mathrm{NaCl}$, $1 \%$ NP-40, $10 \%$ glycerol, $1 \mathrm{mM}$ sodium fluoride supplemented with protease and phosphatase inhibitors. The lysates $(30 \mu \mathrm{g})$ were separated by $10 \%$ SDS-PAGE and transferred to a polyvinylidene difluoride membrane. After blocking with $5 \%$ skimmed milk, the membrane was probed with primary antibody (antiphospho-JNK or antiphospho-c-Jun). The same membranes were stripped and reprobed with anti-JNK, c-Jun, c-Fos, and $\beta$-actin. Blots were developed using HRP-conjugated secondary antibody and visualized using ECL (Amersham).

The expression level of RANK was also determined by western blotting using anti-RANK and anti-ER $\alpha$ antibodies using the protocol described earlier.

\section{Transient transfection assays}

RAW264.7 cells were transfected with a total of $2 \mu \mathrm{g}$ DNA using Amaxa kit (Amaxa Biosystems) according to the manufacturer's protocol. The transfection efficiency was almost $40 \%$. Briefly, $2 \times 10^{6}$ cells were pelletted down and suspended in $100 \mu \mathrm{l}$ Nucleofector Solution V. Afterward, the cells were transfected with pAP1-luc (luciferase reporter plasmid containing three copies of an AP-1 response element) or $p N F-\kappa B-l u c$ reporter plasmid (containing NF- $\kappa \mathrm{B}$ binding site). Another set of cotransfection reactions was set in which RAW264.7 cells were cotransfected with pFR-luc and one of the following plasmids: pFA2-c-Jun (c-Jun), pFA-c-Fos (c-Fos), pFA-ATF2 (ATF2), or pFC-dbd (GAL4). pRL-SV40-luc was also introduced in each case as an internal control. Nucleofector program D-032 was run and the cells were immediately transferred to the DMEM supplemented with $20 \%$ FBS and incubated for $12 \mathrm{~h}$ in the incubator at $37^{\circ} \mathrm{C}$ with $5 \% \mathrm{CO}_{2}$ in humidified chamber. After nucleofection, the cells were scraped, counted, and seeded into a 96-well plate at a density of $2 \times 10^{4}$ cells/well and were incubated with $\mathrm{E}_{2}(0 \cdot 1,1,10$, and $100 \mathrm{nM})$, Ral, or Orm $(10 \mathrm{nM}$, $100 \mathrm{nM}, 1 \mu \mathrm{M}$, and $10 \mu \mathrm{M})$ for $24 \mathrm{~h}$ in the presence of RANKL (200 ng/ml). After $24 \mathrm{~h}$, the cells were lysed; firefly luciferase and Renilla luciferase activities were measured using Dual Luciferase Assay System (Promega). All values were normalized with internal control, i.e. Renilla luciferase. Transcriptional activity was measured as the percentage of normalized luciferase activity, calculated by determining the ratio of normalized luciferase luminescence in the presence of test sample and normalized luciferase luminescence in the unstimulated vehicle-treated group.

\section{Assay of intracellular ROS}

The intracellular generation of ROS was examined using DCFH-DA (Invitrogen) using flow cytometry as described (Lee et al. 2005). In brief, RAW264.7 cells were seeded in a 24-well plate at a density so that they
A
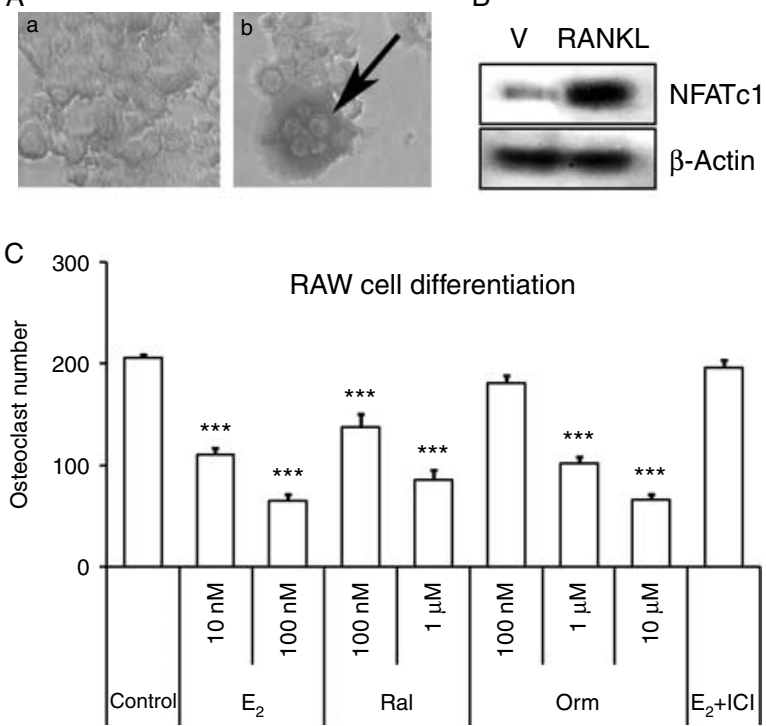

B

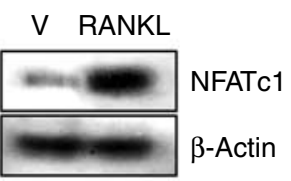

Figure 1 Effect of Orm on osteoclast differentiation in murine RAW264.7 cells. (Panel A) Undifferentiated (a) and differentiated (marked with arrow) (b) RAW264.7 cells. (Panel B) The expression of OC biomarker NFATC1 in differentiated RAW cells. (Panel C) $2 \times 10^{3}$ cells/well were plated in triplicate and multinucleated ( $\geq 3$ nuclei), TRAP-positive osteoclasts were quantified, following induction for 5 days with mouse-soluble RANKL in the presence of vehicle, $17 \beta$-estradiol (10 and $100 \mathrm{nM}$ ), raloxifene (100 $\mathrm{nM}$ and $1 \mu \mathrm{M})$, ormeloxifene $(100 \mathrm{nM}, 1 \mu \mathrm{M}$, and $10 \mu \mathrm{M})$, or $\mathrm{E}_{2}(100 \mathrm{nM})+\mathrm{ICl} 182780(100 \mathrm{nM}) .{ }^{* \star *} P<0.001$ vs control. 
become almost $70 \%$ confluent after $24 \mathrm{~h}$. The next day, the medium of the wells was changed and the cells were incubated with vehicle, $\mathrm{E}_{2}(10$ and $100 \mathrm{nM})$, Ral $(100 \mathrm{nM}$ and $1 \mu \mathrm{M})$, or Orm $(100 \mathrm{nM}, 1 \mu \mathrm{M}$, and $10 \mu \mathrm{M})$ for $24 \mathrm{~h}$ at $37^{\circ} \mathrm{C}$ with $5 \% \mathrm{CO}_{2}$ in humidified incubator. Following incubation, the cells were stimulated with RANKL $(100 \mathrm{ng} / \mathrm{ml})$ for $15 \mathrm{~min}$ at $37^{\circ} \mathrm{C}$. The wells were then washed and incubated in the dark for $30 \mathrm{~min}$ in Krebs-Ringer solution $(125 \mathrm{mM} \mathrm{NaCl}$, $5 \mathrm{mM} \mathrm{KCl}, 25 \mathrm{mM}$ HEPES, $6 \mathrm{mM}$ glucose, $5 \mathrm{mM}$ $\mathrm{NaHCO}_{3}, 1.2 \mathrm{mM} \mathrm{MgSO}_{4}, 1.2 \mathrm{mM} \mathrm{KH}_{2} \mathrm{PO}_{4}$, and $2 \cdot 4 \mathrm{mM} \mathrm{CaCl}_{2}, \mathrm{pH} 7 \cdot 4$ ), containing $5 \mu \mathrm{M}$ DCFH-DA. After treatment with DCFH-DA, cells were washed with PBS thrice, scraped, and suspended in $400 \mu \mathrm{l}$ PBS, and analyzed with a flow cytometer (FACS calibur; BD Biosciences, San Jose, CA, USA). DCF data were recorded at an excitation wavelength of $488 \mathrm{~nm}$ and an emission wavelength of 515-540 nm. The 10000 cells per sample were acquired in histogram using a data analysis program CELL Quest. Dead cells and debris were excluded from the analysis by electronic gating of forward and side scatter measurements.

\section{Statistical analysis}

The values were expressed as mean \pm s.E.M. of three independent experiments. The statistical analysis was performed by one-way ANOVA and the significance was determined by Newman-Keuls test.

\section{Results}

\section{Inhibitory effects of Orm on osteoclast differentiation in RAW264.7 cells}

Monocyte/macrophagic RAW264.7 cells have been described as a model for osteoclast formation (Collin-Osdoby et al. 2003). With a view to determine the potential of Orm to affect the osteoclast differentiation, we evaluated whether RANKL-induced osteoclast formation could be inhibited by the molecule. Stimulation of the RAW264.7 cells with soluble mouse RANKL $(100 \mathrm{ng} / \mathrm{ml})$ for 5 days led to a profound differentiation of the monocyticmacrophagic cell line into multinucleated ( $\geq 3$ nuclei) TRAP-positive cells. In addition to TRAP-positive staining, the cellular differentiation of RAW264.7 cells was also assessed by observing the expression of Nfatc1 (Fig. 1A and B).

Quantitation of the number of multinucleated, TRAP-positive cells present on day 5 after treatment of RAW264.7 cells with $\mathrm{E}_{2}(10$ and $100 \mathrm{nM})$, Ral $(100 \mathrm{nM}$ and $1 \mu \mathrm{M})$, or Orm $(100 \mathrm{nM}, 1 \mu \mathrm{M}$, and $10 \mu \mathrm{M})$ revealed that $\mathrm{E}_{2}$ caused the suppression of RANKL-induced osteoclast formation by almost $70 \%$ at $100 \mathrm{nM}$ concentration while by $50 \%$ at $10 \mathrm{nM}$ concentration. Ral mimicked the effect of $\mathrm{E}_{2}$ in reducing osteoclast formation. Similarly, Orm displayed the antiosteoclastogenic potential in a dose-dependent manner, reducing the TRAP-positive cell number to $50 \%$ at $1 \mu \mathrm{M}$ concentration (Fig. 1C). Treatment of cells with ICI 182780 alone or along with $\mathrm{E}_{2}$ did not caused inhibition in osteoclast formation.

Cell viability assay performed in order to evaluate the cytotoxic potential of Orm, if any, revealed that Orm did not inhibit cell proliferation of RAW264.7 cells at the concentrations used in this study (data not shown).

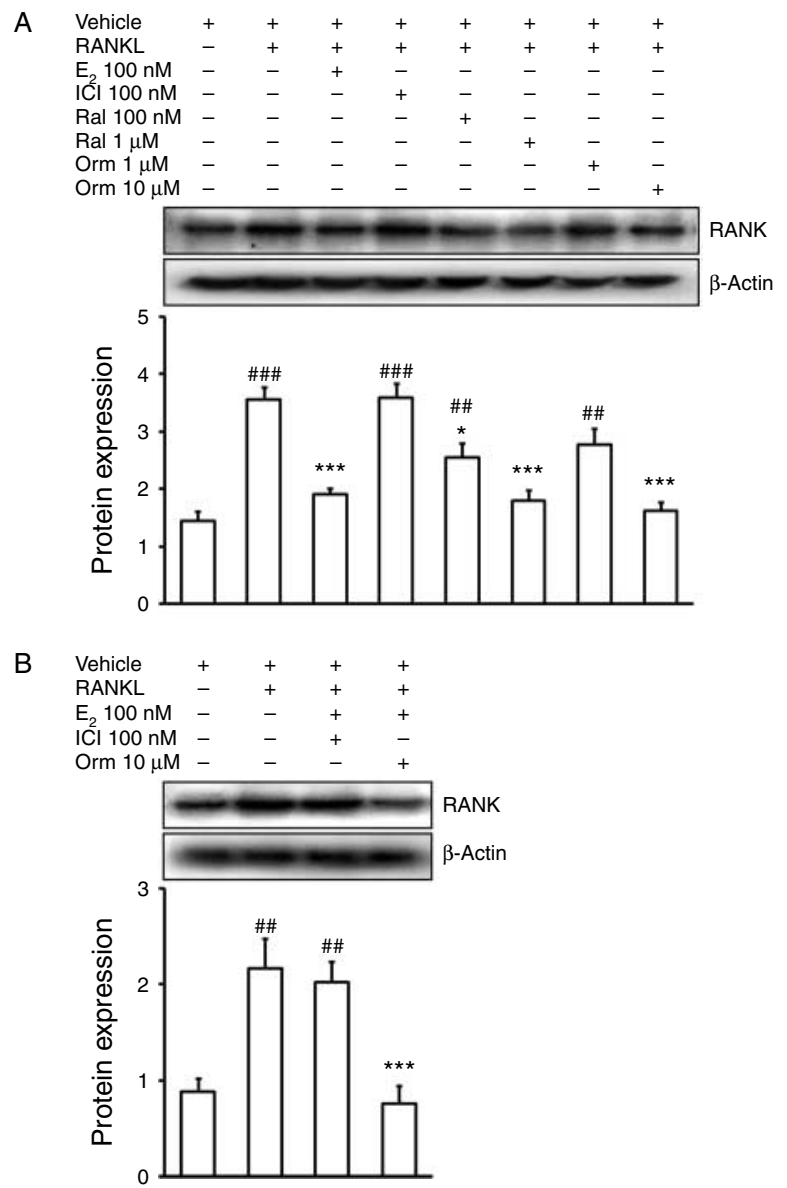

Figure 2 Effect of Orm on RANK expression in RAW cells. (Panel A) RAW264.7 cells incubated with 17 $\beta$-estradiol (100 nM), ICI $182780(100 \mathrm{nM})$, raloxifene $(100 \mathrm{nM}$ and $1 \mu \mathrm{M})$, or ormeloxifene ( 1 and $10 \mu \mathrm{M})$, for $24 \mathrm{~h}$, and then stimulated with $200 \mathrm{ng} / \mathrm{ml}$ of RANKL for $30 \mathrm{~min}$. (Panel B) Cells were incubated with ICl 182780 or Orm in the presence of $E_{2}$ for $24 \mathrm{~h}$ and then stimulated with $200 \mathrm{ng} / \mathrm{ml}$ of RANKL for $30 \mathrm{~min}$. Cell lysates were prepared and subjected to western blotting using specific antibody. The $\beta$-actin blot is shown as a loading control. Quantification of bands was done by densitometric analysis. The results are representative of three independent experiments. ${ }^{\# \# \#} P<0.001,{ }^{\# \#} P<0.01$ vs vehicle and ${ }^{\star \star \star} P<0.001,{ }^{\star} P<0.05$ vs vehicle+RANKL group. 


\section{Effect on RANK expression}

With a view to find out whether Orm caused the suppression of RANK signaling due to altering RANK expression or not, western blot analysis of RANK was performed. The results revealed that Orm
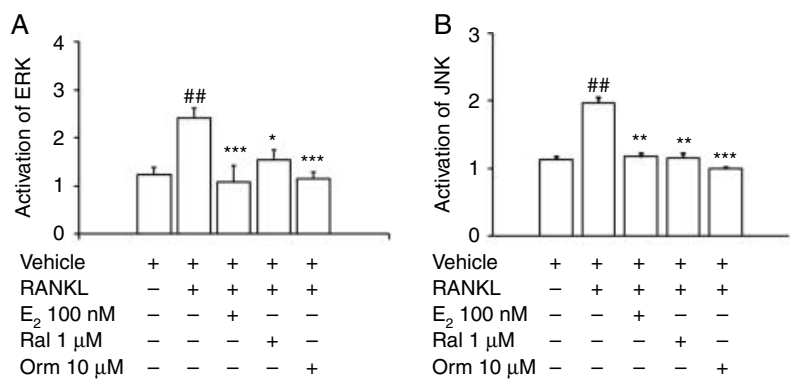

C
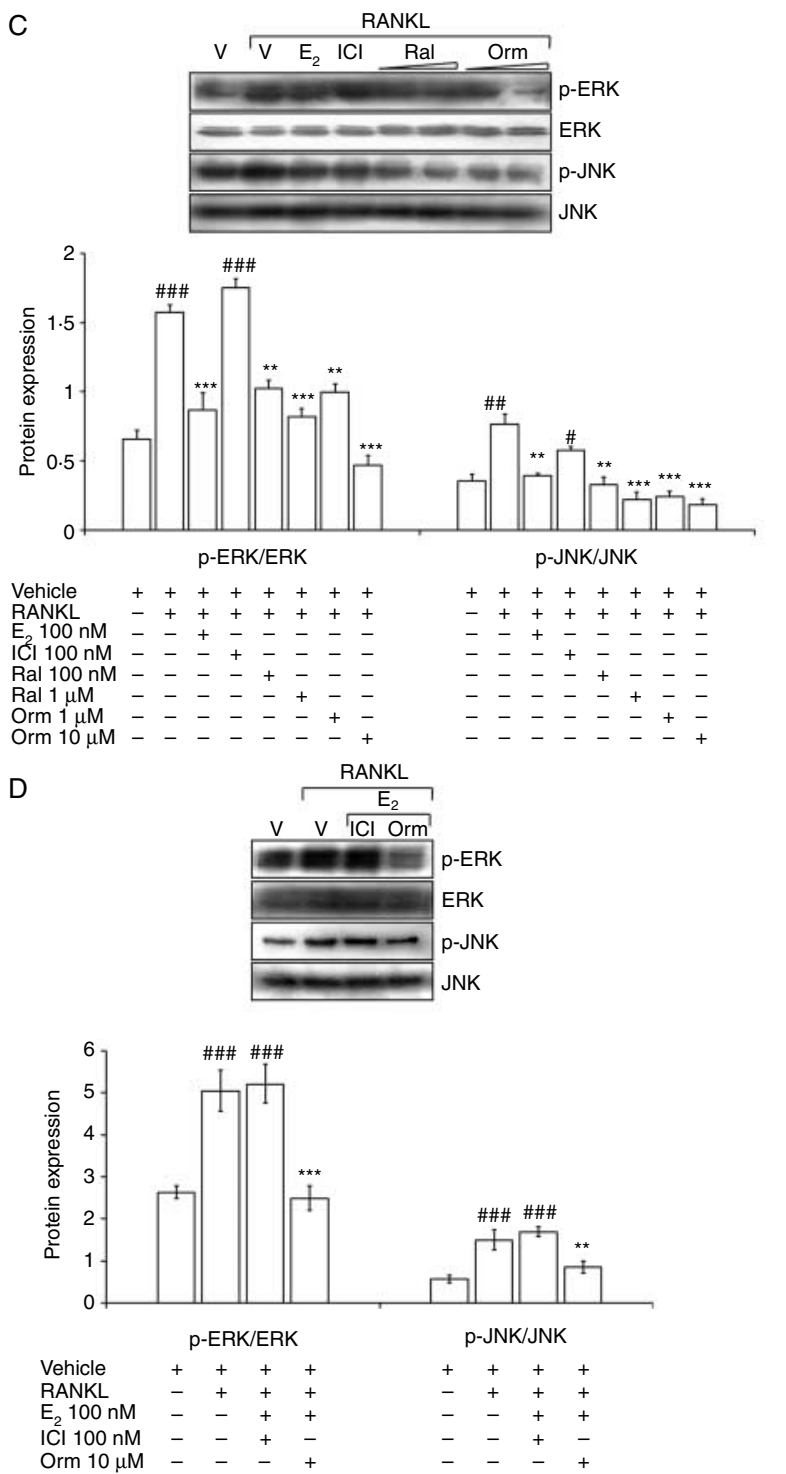

did not cause any significant change $(P>0.05)$ at $10 \mu \mathrm{M}$ concentration (Fig. 2) in RANK expression level. However, at the lower concentration, i.e. $1 \mu \mathrm{M}$ Orm, there was a significant increase in RANK expression $(P<0 \cdot 01)$. RANKL and ICI 182780 induced RANK expression significantly $(P<0 \cdot 001)$.

When cells were incubated with Orm in the presence of $\mathrm{E}_{2}$, no significant change in RANK expression was observed. However, ICI 182 780, in the presence of $\mathrm{E}_{2}$, induced RANK expression significantly $(P<0 \cdot 01$; Fig. 2B).

\section{Suppression of RANK signaling to ERK and JNK MAPKs}

Here, activation of three members of the MAPK family, namely ERK, JNK (also known as SAPK), and p38 was studied. To study the effect of Orm on the MAPK signaling pathway and its comparison with Ral, a known antiresorptive agent, RAW264.7 cells were stimulated with RANKL in the presence of Orm or Ral and the MAPK signaling pathways were examined using antibodies specific for phosphorylated active MAPKs. Both the ERK1/2 and JNK were activated after RANKL stimulation, which was found to be reduced in the presence of $\mathrm{E}_{2}$ as well as Ral (Fig. 3). Orm also caused a reduction in the activation of these two members of MAPK. Orm seem to reduce RANKL-induced JNK activation at $10 \mu \mathrm{M}$ concentration. Treatment of cells with ICI 182780 and $\mathrm{E}_{2}$ could not suppress the RANKLinduced activation of ERK or JNK. No effect of Orm on p38 activation was observed (data not shown).

In order to see specific effects of Orm on activation of ERK and JNK, we performed ELISA and our results have shown that Orm significantly suppressed the RANKL-induced activation of ERK $(P<0 \cdot 001$; Fig. 3A) and JNK $(P<0 \cdot 001$; Fig. 3B $)$.

These results confirmed that RANK signaling was reduced due to the inhibition of the activity of ERK and JNK MAPKs in RAW264.7 cells under the influence of Orm.

Figure 3 Effect of Orm on RANKL-stimulated activation of $p$-JNK and $p$-ERK. (Panel A) Quantified degree of $p$-ERK relative to total ERK expression as determined by ELISA in RAW cells. (Panel B) Quantified degree of $\mathrm{p}$-JNK relative to total JNK expression as determined by ELISA in RAW cells treated with Orm. (Panel C) RAW264.7 cells incubated with 17ß-estradiol (100 nM), $\mathrm{ICl} 182780(100 \mathrm{nM})$, raloxifene $(100 \mathrm{nM}$ and $1 \mu \mathrm{M})$, or ormeloxifene ( 1 and $10 \mu \mathrm{M})$, for $24 \mathrm{~h}$, and then stimulated with $200 \mathrm{ng} / \mathrm{ml}$ of RANKL for $30 \mathrm{~min}$. (Panel D) Cells were incubated with ICl 182780 or Orm in the presence of $E_{2}$ for $24 \mathrm{~h}$ and then stimulated with $200 \mathrm{ng} / \mathrm{ml}$ RANKL for $30 \mathrm{~min}$. Cell lysates were prepared and subjected to western blotting using specific antibody. Quantification of bands was done by densitometric analysis. The results are representative of three independent experiments. ${ }^{\# \#} P<0.001,{ }^{\# \#} P<0.01,{ }^{\#} P<0.05$ vs vehicle and ${ }^{\star \star \star} P<0.001,{ }^{\star \star} P<0.01,{ }^{\star} P<0.05$ vs vehicle + RANKL group. 


\section{Interference with RANKL-induced expression and activation of AP-1 transcription complex partners}

As the MAPKs get activated, they translocate into the nucleus and affect the expression and activation of various transcription factors that include c-Fos and c-Jun. c-Fos is considered to be the main target of the ERK pathway while c-Jun is known to get activated in a downstream pathway triggered after JNK activation. As the RANKL-induced ERK and JNK activation was affected by Orm, the expression level of c-Fos and c-Jun was investigated. When RAW264.7 cells were incubated with $\mathrm{E}_{2}$, Ral, and Orm for $24 \mathrm{~h}$ and stimulated with RANKL, it was observed that $\mathrm{E}_{2}$ and Ral effectively blunted c-Fos expression. Its expression was found to be reduced in a dose-dependent manner after incubation with Orm, similar to that observed in the vehicle-treated group at $10 \mu \mathrm{M}$ concentration (Fig. 4). Activation and expression analysis of c-Jun revealed no prominent change in the Ral-treated group. The expression of c-Jun was provoked by RANKL and Orm was effective in suppressing the levels of phosphorylated c-Jun at 1 and $10 \mu \mathrm{M}$ concentrations.

It was interesting to note that the decrease in c-Fos and c-Jun expression and activation was associated with a corresponding decline in RAW264.7 cell transcription, as measured by a significant decrease $(P<0 \cdot 001)$ in luciferase reporter gene activity under AP-1 control at $10 \mu \mathrm{M}$ concentration when the cells were incubated with Orm (Fig. 5A).

Further, the ability of RANKL to stimulate the transcriptional activity of transfected chimeric genes composed of the DNA-binding domain of GAL4 (pFC-dbd) fused to the activation domains of c-Jun, c-Fos, or ATF2 was examined. Transcriptional activity of pFA-c-Jun was significantly increased by more than threefold after RANKL stimulation (Fig. 5B). $\mathrm{E}_{2}$ effectively blunted c-Jun transactivation. Orm caused suppression of c-Jun transactivation, which was also shown by Ral at 1 and $10 \mu \mathrm{M}$ concentration. Mild activation of pFA-c-Fos and pFA-ATF2 was observed on stimulation with RANKL. Ral caused a decrease in transactivation of pFA-c-Fos and pFA-ATF2 at as low as $100 \mathrm{nM}$ (Fig. 5B). Orm did not affect the transactivation of c-Fos at lower concentrations, but it was similar to that of the unstimulated control at $10 \mu \mathrm{M}$ concentration. By contrast, ATF2 transactivation was not suppressed significantly by Orm, suggesting that Orm may not interfere with the ATF2 activity while forming the transcription complex at AP-1 site. $\mathrm{E}_{2}$ almost completely blocked induction of each chimera by RANKL and so did Orm and Ral. These findings advocate the role of Orm in affecting transcriptional complex formation as well as the transcriptional activity of transcriptional partners, thereby repressing osteoclast formation.
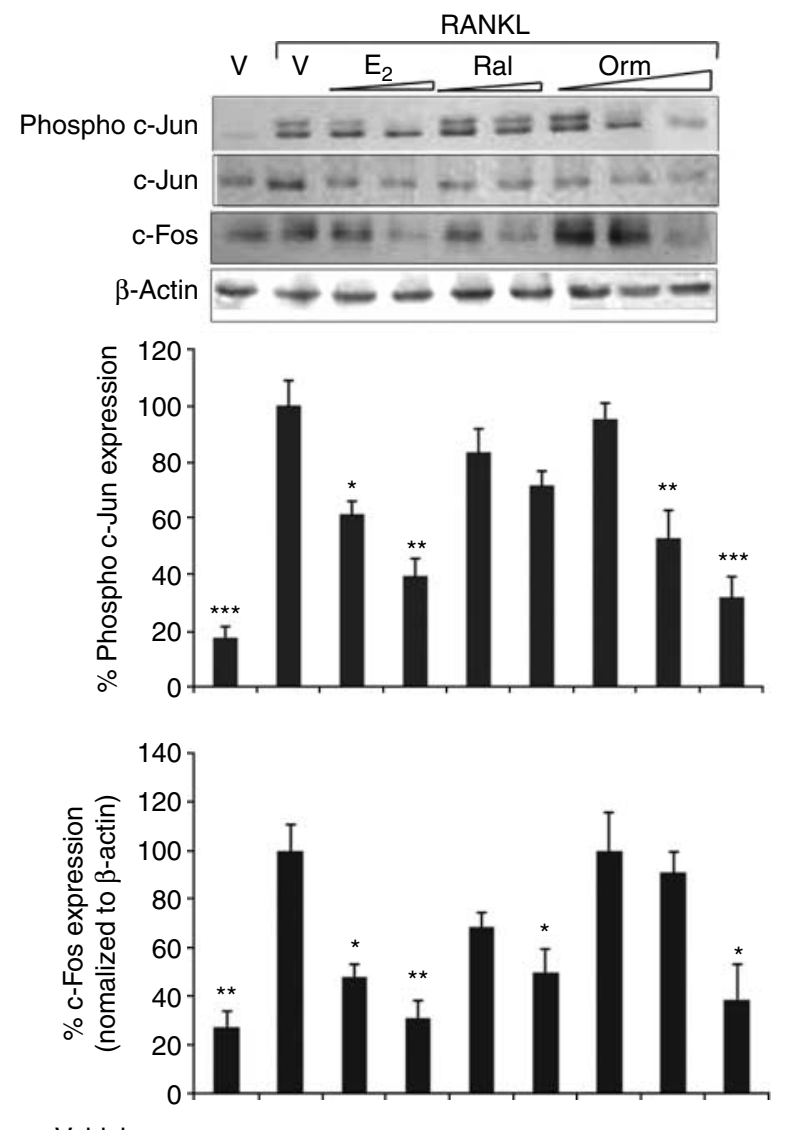

$\begin{array}{llllllllll}\text { Vehicle } & + & + & + & + & + & + & + & + & + \\ \text { RANKL } & - & + & + & + & + & + & + & + & + \\ \mathrm{E}_{2} 10 \mathrm{nM} & - & - & + & - & - & - & - & - & - \\ \mathrm{E}_{2} 100 \mathrm{nM} & - & - & - & + & - & - & - & - & - \\ \mathrm{Ral} 100 \mathrm{nM} & - & - & - & - & + & - & - & - & - \\ \text { Ral } 1 \mu \mathrm{M} & - & - & - & - & - & + & - & - & - \\ \text { Orm } 100 \mu \mathrm{M} & - & - & - & - & - & - & + & - & - \\ \text { Orm } 1 \mu \mathrm{M} & - & - & - & - & - & - & - & + & - \\ \text { Orm } 10 \mu \mathrm{M} & - & - & - & - & - & - & - & - & +\end{array}$

Figure 4 Effect of Orm on the RANKL-induced expression of p-c-Jun, c-Jun, and c-Fos. RAW264.7 cells were incubated with different concentrations of $17 \beta$-estradiol (10 and $100 \mathrm{nM})$, raloxifene (100 $\mathrm{nM}$ and $1 \mu \mathrm{M})$, or ormeloxifene $(100 \mathrm{nM}, 1 \mu \mathrm{M}$, and $10 \mu \mathrm{M})$ for $24 \mathrm{~h}$ and then stimulated with $200 \mathrm{ng} / \mathrm{ml} \mathrm{RANKL}$ for $30 \mathrm{~min}$. Cell lysates were prepared and subjected to western blotting with the specific antibodies. The $\beta$-actin blot is shown as a loading control. Quantification of bands was done by densitometric analysis. The results are representative of three independent experiments. ${ }^{\star \star \star} P<0.001,{ }^{\star \star} P<0.01,{ }^{\star} P<0.05$ vs vehicle + RANKL group.

\section{Effect on transcriptional activation of NF-кB}

Activation of the NF- $\kappa \mathrm{B}$ transcription factor is an essential step for osteoclast differentiation that takes place via activation of I $\kappa \mathrm{b}$. Studies suggest that severe osteoporosis develops and mature osteoclasts fail to generate in mice deficient in both the p50 and p52 subunits of NF-кB (Franzoso et al. 1997). Therefore, 


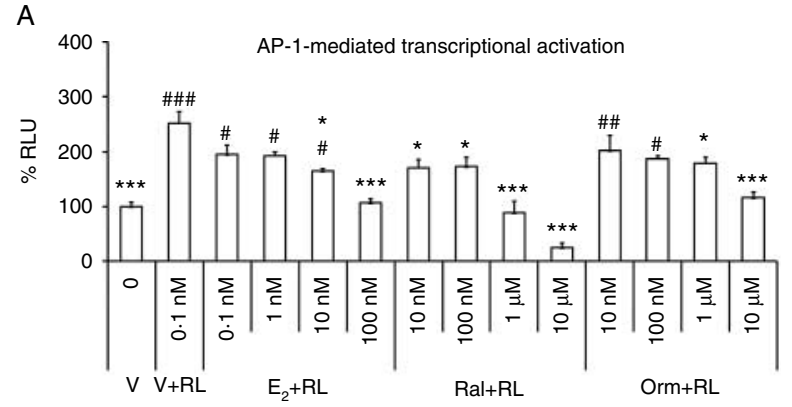

B C-Jun-mediated transcriptional activation
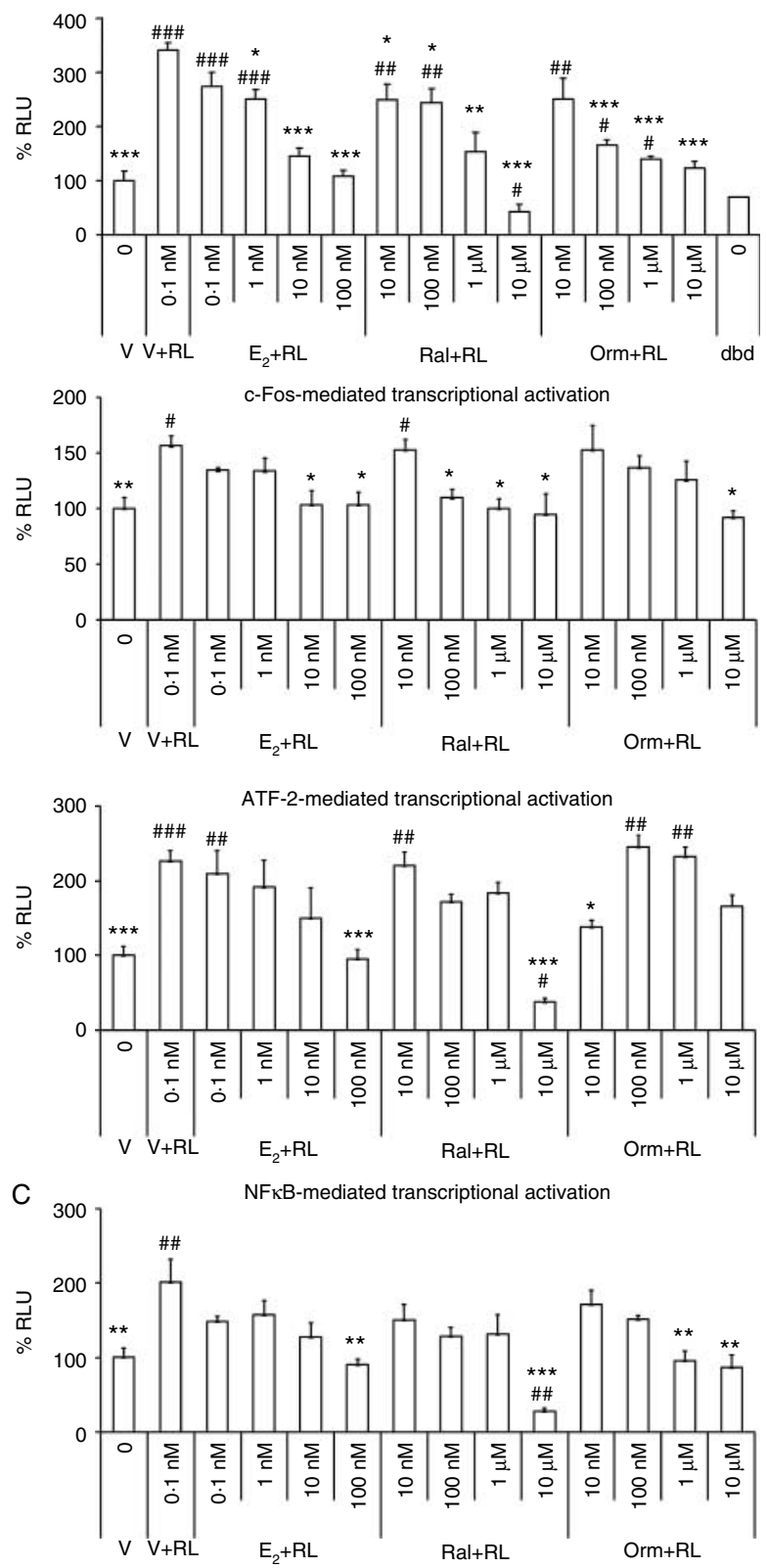

we next determined whether Orm has any role in affecting NF- $\kappa \mathrm{B}$ activation by RANKL. For this, a luciferase reporter construct with a NF- $\kappa \mathrm{B}$ binding site was introduced into the RAW264.7 cells, and luciferase activity was determined after incubating the transfected cells with $\mathrm{E}_{2}$, Ral, or Orm for $24 \mathrm{~h}$. It was observed that RANKL induced transactivation via NF- $\mathrm{B}$ almost twofold, which was reduced to the levels similar to that of unstimulated control in the presence of $100 \mathrm{nM} \mathrm{E}$. Orm was able to attenuate the NF- $\kappa \mathrm{B}$ activity to almost a similar level at $1 \mu \mathrm{M}$ concentration (Fig. 5C), suggesting a possible role of Orm by suppressing the activation of $\mathrm{NF}-\kappa \mathrm{B}$ in mediating its antiosteoclastogenic potential.

\section{Influence on RANKL-stimulated ROS generation}

The effect of Orm on ROS generation was evaluated after stimulation of RAW264.7 cells with RANKL. Intracellular ROS was measured using the cellpermeable, oxidation-sensitive dye DCFH-DA by FACS, and it was found that ROS was increased by stimulation with RANKL and also that Orm was able to inhibit its increase after RANKL induction. $\mathrm{E}_{2}$ and Ral also very effectively caused decrease in ROS generation $(P<0 \cdot 001$; Fig. 6 , data not shown).

\section{Discussion}

An understanding of the mechanism of the protective effects of estrogen and SERMs in bone has very important implications for the prevention and treatment of osteoporosis. Several bone-protective compounds, such as tamoxifen and Ral (Clemett \& Spencer 2000, Goldstein 2010), oppose the differentiating effects of RANKL and reduce the formation of osteoclast-like cells from undifferentiated precursors. Orm is known to prevent ovariectomy-induced bone

Figure 5 Effect of Orm on RANKL-induced activation of AP-1, c-Jun, c-Fos, ATF2, or NF- $\kappa$ B-mediated transcription in RAW264.7 cells. (Panel A) Cells were transfected with a luciferase reporter plasmid $p A P 1-l u c$. (Panel B) Cells were transfected with a luciferase reporter plasmid $p F R$-luc containing GAL4 binding site along with activator plasmids, pFA2-c-Jun, pFA-c-Fos, or pFA-ATF2. pFC-dbd (GAL4) was also transfected as negative control. (Panel C) Cells were transfected with a luciferase reporter plasmid containing $\mathrm{NF}-\kappa \mathrm{B}$-binding sequence. $12 \mathrm{~h}$ after nucleofection, the cells were scraped, counted, and seeded into a 96-well plate at a density of $2 \times 10^{4}$ cells/well and were incubated with $\mathrm{E}_{2}(0 \cdot 1,1,10$, and $100 \mathrm{nM})$, Ral, or Orm (10 nM, $100 \mathrm{nM}, 1 \mu \mathrm{M}, 10 \mu \mathrm{M})$ for $24 \mathrm{~h}$ in the presence of RANKL $(200 \mathrm{ng} / \mathrm{ml})$. After $24 \mathrm{~h}$, the cells were lysed; firefly luciferase and Renilla luciferase activities were measured as relative light units (RLU). Percent transcriptional activity was measured as percentage of normalized luciferase activity of unstimulated vehicle-treated group. The results are representative of three independent experiments. ${ }^{\star \star \star} P<0.001,{ }^{\star \star} P<0.01$, ${ }^{\star} P<0.05$ vs V $+\mathrm{RL}$; ${ }^{\# \# \#} P<0.001,{ }^{\# \#} P<0.01,{ }^{\#} P<0.05$ vs $100 \mathrm{nM} \mathrm{E}_{2}$. 


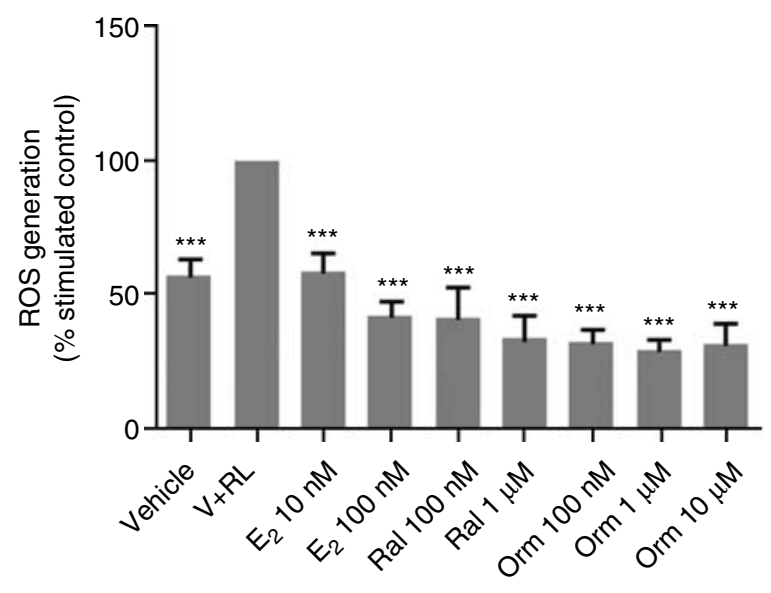

Figure 6 Decrease in RANKL-induced ROS production by Orm in RAW264.7 cells. Cells were pretreated with different concentrations of $E_{2}(10$ and $100 \mathrm{nM})$, Ral (100 nM and $\left.1 \mu \mathrm{M}\right)$, or Orm (100 nM, $1 \mu \mathrm{M}$, and $10 \mu \mathrm{M})$ for $24 \mathrm{~h}$, preloaded with DCFH-DA, and treated with RANKL $(100 \mathrm{ng} / \mathrm{ml})$ for $10 \mathrm{~min}$. DCF fluorescence was detected with flow cytometry. Results are expressed as the percentage mean fluorescence intensity of unstimulated vehicle-treated control. The results are representative of three independent experiments. ${ }^{\star \star \star} P<0.001$ vs stimulated control $(\mathrm{V}+\mathrm{RL})$.

loss in rats (Arshad et al. 2004, Narayana Murthy et al. 2006). This study was carried out to investigate the influence of Orm on the generation of osteoclast and its mechanism of action using an in vitro model system, i.e. murine RAW264.7 cells. The RAW264.7 cell line is derived from murine macrophages and has been used as the in vitro target of the cloned rat RANKL gene (Xu et al. 2000). These cells serve as an excellent model of osteoclast differentiation as RANKL treatment induces their differentiation into osteoclast-like, TRAPpositive cells (David et al. 2002, Yamamoto et al. 2002, Collin-Osdoby et al. 2003). The advantage of this system is that it does not contain any osteoblast/bone marrow stromal cells or cytokine-like macrophage CSF and allows focusing on RANKL signaling in preosteoclast cells.

Our study has demonstrated that Orm can attenuate RANKL-induced osteoclast formation in preosteoclast RAW264.7 cells by suppressing cellular responsiveness to osteoclastogenic factor such as RANKL, an effect that is comparable to that of estrogen. Our results also exclude the possibility of cytotoxicity by Orm, as was evident from the cell viability data.

To gain insight into the molecular mechanisms involved in osteoclast differentiation, the intracellular signaling pathways engaged by RANKL was investigated. JNKs and ERKs are two MAPKs among the family that have been shown to be involved in osteoclastogenesis in in vitro cell culture (Shevde et al. 2000, Thalhamer et al. 2008). RANKL stimulates JNK and subsequently enhances c-Jun activation (Lee et al. 2001, 2002, Ikeda et al. 2004). Therefore, we assessed the level of phosphorylated JNK in response to RANKL treatment.
Here, Orm and Ral acted similar to $\mathrm{E}_{2}$ in blunting the phosphorylation of JNK and also of c-Jun. Further, ERK, another MAPK, is known to play a functional role not only in osteoclast differentiation but also in its survival (Lee et al. 2001, 2002, Wagner 2002). Orm suppressed the activation of ERK in response to RANKL (Fig. 3). Collectively, the ERK and JNK MAPKs appeared to be the major signaling pathways downregulated by Orm.

The AP-1 transcription factor is a heteromeric protein complex composed of members of Fos, Jun, and ATF families. RANKL is known to activate the AP-1 transcription factor complex, partly through the induction of its critical component c-Fos (Wagner \& Eferl 2005). AP-1mediated transcription is known to play an important role in RANK-regulated osteoclastogenesis (Shevde et al. 2000). Orm caused effective suppression in AP-1 transactivation. The suppression of c-Jun has been reported by other groups earlier in the presence of SERMs, e.g. Ral and tamoxifen (Clemett \& Spencer 2000, Lee et al. 2001). The suppressive effect of Orm on these multiple transcription factors are likely to contribute to the inhibition of osteoclast differentiation and c-Jun-mediated transactivation in the RAW264.7 cells.

Several transcription factors are known to mediate induction of genes implicated in osteoclastic differentiation in response to RANKL. The NF- $\mathrm{BB}$ transcription factor is the first one characterized to be activated downstream of RANK. NF-KB is activated by RANKL both in monocytes and RAW264.7 cells (Srivastava et al. 2001, Collin-Osdoby et al. 2003) and is required in vivo for osteoclast formation (Franzoso et al. 1997). It is also reported that ER directly inhibits IL6 gene expression by disruption of NF- $\mathrm{KB}$ transactivation (Stein \& Yang 1995). In this study, Orm was observed to decrease the transcriptional activation of NF- $\mathrm{B}$ induced by RANKL. Similar effects were observed in Ral-treated groups as reported earlier (Bellosta $e t$ al. 2007, Lee $e t$ al. 2008). The attenuation of NF-kB by Orm might lead to suppression of cytokines, e.g. IL6. A recent study suggested that NF- $\kappa \mathrm{B}$ is also an upstream transcription factor modulating the expression of Nfatc1 (Takatsuna et al. 2005). Therefore, another possibility may be that Orm affects the expression of Nfatcl, thereby displaying its property to decrease osteoclast differentiation, although this needs to be examined further.

It is documented that in bone marrow-derived macrophages stimulated with RANKL, intracellular levels of ROS were increased through the RANKLTRAF6-Rac1-NADPH oxidase (Nox) 1 pathway (Lee et al. 2005). The generated ROS is reported to act as an intracellular signal mediator for the activation of MAPKs by RANKL in osteoclast differentiation (Lee $e t$ al. 2005). Estrogen helps in preventing bone loss by a mechanism involving blunting the production of ROS (Chen et al. 2008). Recently, a lignan, sauchinone, having antiosteoclastogenic activity has been reported 
to decrease ROS levels in BMM cells, which was described to mediate its osteoclastogenic effect (Han et al. 2007). There are reports that $N$-acetylcysteine inhibits the response of BMM cells to RANKL including ROS production (Lee et al. 2005). Our results also demonstrated that RANKL-stimulated ROS generation was decreased in the cells that were treated with Orm. In addition, RANKL-activated ROS is known to induce mitochondrial biogenesis. The signaling pathways controlling osteoclast differentiation and mitochondrial biogenesis cross talk and synergistically promote osteoclastogenesis (Wan 2010). Therefore, in light of our findings, the two mechanisms controlling osteoclastogenesis by Orm may be postulated: the first possibility may be that due to the ROS inhibitory action of Orm, the activation of MAPKs and subsequent signaling events are suppressed. In addition to this, the second mechanism may involve the suppression of cross talk mechanisms between signaling pathways of OC differentiation and the mitochondrial biogenesis.

Taken together, the study demonstrated that Orm inhibits RANKL-induced osteoclastogenesis by reducing ROS generation and attenuates MAPK, AP-1, and $\mathrm{NF}-\kappa \mathrm{B}$ activation, ultimately leading to the suppression of downstream signaling molecules. These results provide a possible mechanism of action of Orm in regulating osteoclastogenesis, thereby supporting the potential of this compound toward the beneficial and protective effects on the bone.

\section{Declaration of interest}

The authors declare that there is no conflict of interest that could be perceived as prejudicing the impartiality of the research reported.

\section{Funding}

This work was supported by Council of Scientific and Industrial Research, New Delhi and Ministry of Health and Family Welfare, Govt of India.

\section{Acknowledgements}

The authors are grateful to Dr Manoj Barthwal, Pharmacology Division for his help in transfection studies and to Mr A L Vishwakarma, SAIF for flow cytometric analysis. The authors sincerely thank Dr Naibedya Chattopadhyay for his valuable discussions.

\section{References}

Arshad M, Sengupta S, Sharma S, Ghosh R, Sawlani V \& Singh M 2004 In vitro anti-resorptive activity and prevention of ovariectomyinduced osteoporosis in female Sprague-Dawley rats by ormeloxifene, a selective estrogen receptor modulator. Journal of Steroid Biochemistry and Molecular Biology 91 67-78. (doi:10.1016/j.jsbmb. 2004.02.010)
Asagiri M \& Takayanagi H 2007 The molecular understanding of osteoclast differentiation. Bone 40 251-264. (doi:10.1016/j.bone. 2006.09.023)

Awasthi S, Daverey A \& Dwivedi A 2007 Modulation of AP-1 mediated estrogenic response by ormeloxifene in rat uterus. Journal of Steroid Biochemistry and Molecular Biology 104 208-214. (doi:10.1016/j. jsbmb.2007.03.029)

Bellosta S, Baetta R, Canavesi M, Comparato C, Granata A, Monetti M, Cairoli F, Eberini I, Puglisi L \& Corsini A 2007 Raloxifene inhibits matrix metalloproteinases expression and activity in macrophages and smooth muscle cells. Pharmacological Research 56 160-167. (doi:10.1016/j.phrs.2007.05.004)

Blesson CS, Awasthi S, Kharkwal G, Daverey A \& Dwivedi A 2006 Modulation of estrogen receptor transactivation and estrogeninduced gene expression by ormeloxifene-a triphenylethylene derivative. Steroids 71 993-1000. (doi:10.1016/j.steroids.2006.08. 001)

Boyle WJ, Simonet WS \& Lacey DL 2003 Osteoclast differentiation and activation. Nature 423 337-342. (doi:10.1038/nature01658)

Chen JR, Shankar K, Nagarajan S, Badger TM \& Ronis MJ 2008 Protective effects of estradiol on ethanol-induced bone loss involve inhibition of reactive oxygen species generation in osteoblasts and downstream activation of the extracellular signal-regulated kinase/signal transducer and activator of transcription 3/receptor activator of nuclear factor-kappaB ligand signaling cascade. Journal of Pharmacology E Experimental Therapeutics 324 50-59. (doi:10.1124/jpet.107.130351)

Clemett D \& Spencer CM 2000 Raloxifene: a review of its use in postmenopausal osteoporosis. Drugs 60 379-411. (doi:10.2165/ 00003495-200060020-00013)

Collin-Osdoby P, Yu X, Zheng H \& Osdoby P 2003 RANKL-mediated osteoclast formation from murine RAW 264.7 cells. Methods in Molecular Medicine 80 153-166. (doi:10.1385/1-59259-366-6:153)

Darnay BG, Ni J, Moore PA \& Aggarwal BB 1999 Activation of NF-kappaB by RANK requires tumor necrosis factor receptorassociated factor (TRAF) 6 and NF-kappaB-inducing kinase. Identification of a novel TRAF6 interaction motif. Journal of Biological Chemistry 274 7724-7731. (doi:10.1074/jbc.274.12.7724)

Daverey A, Saxena R, Tewari S, Goel SK \& Dwivedi A 2009 Expression of estrogen receptor co-regulators SRC-1, RIP140 and NCoR and their interaction with estrogen receptor in rat uterus, under the influence of ormeloxifene. Journal of Steroid Biochemistry and Molecular Biology 116 93-101. (doi:10.1016/j.jsbmb.2009.05.006)

David JP, Sabapathy K, Hoffmann O, Idarraga MH \& Wagner EF 2002 JNK1 modulates osteoclastogenesis through both c-Jun phosphorylation-dependent and -independent mechanisms. Journal of Cellular Sciences 115 4317-4325. (doi:10.1242/jcs.00082)

Forman HJ, Fukuto JM \& Torres M 2004 Redox signaling: thiol chemistry defines which reactive oxygen and nitrogen species can act as second messengers. American Journal of Physiology 287 C246-C256. (doi:10.1152/ajpcell.00516.2003)

Franzoso G, Carlson L, Xing L, Poljak L, Shores EW, Brown KD, Leonardi A, Tran T, Boyce BF \& Siebenlist U 1997 Requirement for NF-kappaB in osteoclast and B-cell development. Genes and Development 11 3482-3496. (doi:10.1101/gad.11.24.3482)

Galal N, Waleed R, El-Beialy WR, Deyama Y, Yoshimura Y, Suzuki K \& Totsuka Y 2007 Novel effect of estrogen on RANK and c-fms expression in RAW 264.7 cells. International Journal of Molecular Medicine 20 97-101.

Goldstein SR 2010 Selective estrogen receptor modulator: the saga continues. Menopause 17 231-232. (doi:10.1097/gme. 0b013e3181d12e65)

Han KY, Yang D, Chang EJ, Lee Y, Huang H, Sung SH, Lee ZH, Kim YC \& Kim HH 2007 Inhibition of osteoclast differentiation and bone resorption by sauchinone. Biochemical Pharmacology 74 911-923. (doi:10.1016/j.bcp.2007.06.044)

Hsu H, Lacey DL, Dunstan CR, Solovyev I, Colombero A, Timms E, Tan H-L, Elliott G, Kelley MJ, Sarosi I et al. 1999 Tumor necrosis 
factor receptor family member RANK mediates osteoclast differentiation and activation induced by osteoprotegerin ligand. PNAS 96 3540-3545. (doi:10.1073/pnas.96.7.3540)

Ikeda F, Nishimura R, Matsubara T, Tanaka S, Inoue J, Reddy SV, Hata K, Yamashita K, Hiraga T, Watanabe T et al. 2004 Critical roles of c-Jun signaling in regulation of NFAT family and RANKLregulated osteoclast differentiation. Journal of Clinical Investigation 114 475-484. (doi:10.1172/JCI19657)

Jilka RL, Hangoc G, Girasole G, Passeri G, Williams DC, Abrams JS, Boyce B, Broxmeyer H \& Manolagas SC 2001 Estrogen decreases osteoclast formation by down-regulating receptor activator of NF-kappa B ligand (RANKL)-induced JNK activation. Journal of Biological Chemistry 276 8836-8840. (doi:10.1074/jbc. M010764200)

Kim Y, Sato K, Asagiri M, Morita I, Soma K \& Takayanagi H 2005 Contribution of nuclear factor of activated $\mathrm{T}$ cells $\mathrm{cl}$ to the transcriptional control of immunoreceptor osteoclast-associated receptor but not triggering receptor expressed by myeloid cells-2 during osteoclastogenesis. Journal of Biological Chemistry 280 32905-32913. (doi:10.1074/jbc.M505820200)

Kim MH, Ryu SY, Choi JS, Min YK \& Kim SH 2009 Saurolactam inhibits osteoclast differentiation and stimulates apoptosis of mature osteoclasts. Journal of Cellular Physiology 221 618-628. (doi:10.1002/ jcp.21892)

Lean JM, Davis JT, Fuller K, Jagger CJ, Kirsten B, Partington GA, Urry ZL \& Chambers TJ 2003 A crucial role for thiol antioxidants in estrogen-deficiency bone loss. Journal of Clinical Investigation 112 915-923. (doi:10.1172/JCI18859)

Lee ZH \& Kim HH 2003 Signal transduction by receptor activator of nuclear factor kappaB in osteoclasts. Biochemical and Biophysical Research Communications 305 211-214. (doi:10.1016/S0006291X(03)00695-8)

Lee SE, Chung WJ, Kwak HB, Chung CH, Kwack KB, Lee ZH \& Kim HH 2001 Tumor necrosis factor- $\alpha$ supports the survival of osteoclasts through the activation of Akt and ERK. Journal of Biological Chemistry 276 49343-49349. (doi:10.1074/jbc. M103642200)

Lee SE, Woo KM, Kim SY, Kim HM, Kwack K, Lee ZH \& Kim HH 2002 The phosphatidylinositol 3-kinase, p38, and extracellular signalregulated kinase pathways are involved in osteoclast differentiation. Bone 30 71-77. (doi:10.1016/S8756-3282(01)00657-3)

Lee NK, Choi YG, Baik JY, Han SY, Jeong DW, Bae YS, Kim N \& Lee SY 2005 A crucial role for reactive oxygen species in RANKL-induced osteoclast differentiation. Blood 106 852-859. (doi:10.1182/blood2004-09-3662)

Lee SA, Park SH \& Kim BC 2008 Raloxifene, a selective estrogen receptor modulator, inhibits lipopolysaccharide-induced nitric oxide production by inhibiting the phosphatidylinositol 3-kinase/Akt/nuclear factor-kappa B pathway in RAW264.7 macrophage cells. Molecules and Cells 26 48-52.

Maggio D, Barabani M, Pierandrei M, Polidori MC, Catani M, Mecocci P, Senin U, Pacifici R \& Cherubini A 2003 Marked decrease in plasma antioxidants in aged osteoporotic women: results of a cross-sectional study. Journal of Clinical Endocrinology and Metabolism 88 1523-1527. (doi:10.1210/jc.2002-021496)

Misra NC, Nigam PK, Gupta R, Agarwal AK \& Kamboj VP 1989 Centchroman: a non-steroidal anticancer agent for advanced breast cancer: phase II study. International Journal of Cancer 43 781-783. (doi:10.1002/ijc.2910430506)

Nakamura T, Imai Y, Matsumoto T, Sato S, Takeuchi K, Igarashi K, Harada Y, Azuma Y, Krust A, Yamamoto Y et al. 2007 Estrogen prevents bone loss via estrogen receptor $\alpha$ and induction of Fas ligand in osteoclasts. Cell 130 811-823. (doi:10.1016/j.cell.2007. 07.025)

Narayana Murthy PS, Sengupta S, Sharma S \& Singh MM 2006 Effect of ormeloxifene on ovariectomy-induced bone resorption, osteoclast differentiation and apoptosis and TGF $\beta-3$ expression. Journal of Steroid Biochemistry and Molecular Biology 100 117-128. (doi:10.1016/ j.jsbmb.2006.03.009)

Riggs BL, Khosla S \& Melton LJ III 2002 Sex steroids and the construction and conservation of the adult skeleton. Endocrine Reviews 23 279-302. (doi:10.1210/er.23.3.279)

Saintier D, Khanine V, Uzan B, Ea HK, de Vernejoul MC \& Cohen-Solal ME 2006 Estradiol inhibits adhesion and promotes apoptosis in murine osteoclasts in vitro. Journal of Steroid Biochemistry and Molecular Biology 99 165-173. (doi:10.1016/j.jsbmb. 2006.01.009)

Shevde NK, Bendixen AC, Dienger KM \& Pike JW 2000 Estrogens suppress RANK ligand-induced osteoclast differentiation via a stromal cell independent mechanism involving c-Jun repression. PNAS 97 7829-7834. (doi:10.1073/pnas.130200197)

Singh M 2001 Centchroman, a selective estrogen receptor modulator, as a contraceptive and for the management of hormone-related clinical disorders. Medicinal Research Reviews 21 302-347. (doi:10.1002/med.1011)

Srivastava S, Toraldo G, Weitzmann MN, Cenci S, Ross FP \& Pacifici R 2001 Estrogen decreases osteoclast formation by down-regulating receptor activator of NF-kappa B ligand (RANKL)-induced JNK activation. Journal of Biological Chemistry 276 8836-8840. (doi:10.1074/jbc.M010764200)

Stein B \& Yang MX 1995 Repression of the interleukin-6 promoter by estrogen receptor is mediated by NF-kappa B and C/EBP $\beta$. Molecular and Cellular Biology 159.

Syed F \& Khosla S 2003 Mechanisms of sex steroid effects on bone. Biochemical and Biophysical Research Communications 328 688-696. (doi:10.1016/j.bbrc.2004.11.097)

Takatsuna H, Asagiri M, Kubota T, Oka K, Osada T, Sugiyama C, Saito H, Aoki K, Ohya K, Takayanagi $\mathrm{H}$ et al. 2005 Inhibition of RANKL-induced osteoclastogenesis by (-)-DHMEQ, a novel NF-kappaB inhibitor, through downregulation of NFATc1. Journal of Bone and Mineral Research 20 653-662. (doi:10.1359/ JBMR.041213)

Thalhamer T, McGrath MA \& Harnett MM 2008 MAP kinases and their relevance to arthritis and inflammation. Rheumatology 47 409-414. (doi:10.1093/rheumatology/kem297)

Tripathi S, Dwivedy I, Dhar JD, Dwivedi A \& Ray S 1997 Evaluation of piperidinoethoxy moiety as an antiestrogenic substitute in non-steroidal antiestrogens: fertility regulation. Bioorganic $\mathcal{E}$ Medicinal Chemistry Letters 7 2131-2136. (doi:10.1016/S0960-894X (97)00379-X)

Wagner EF 2002 Functions of AP1 (Fos/Jun) in bone development. Annals of Rheumatic Disease 61 (Suppl 2) ii40-ii42. (doi:10.1136/ard. 61.suppl_2.ii40)

Wagner EF \& Eferl R 2005 Fos/AP-1 protein in bone and the immune system. Immunological Reviews 208 126-140. (doi:10.1111/j.01052896.2005.00332.x)

Wan Y 2010 PPAR $\gamma$ in bone homeostasis. Trends in Endocrinology and Metabolism 21 722-728. (doi:10.1016/j.tem.2010.08.006)

Xu J, Tan JW, Huang L, Gao XH, Laird R, Liu D, Wysocki S \& Zheng MH 2000 Cloning, sequencing, and functional characterization of the rat homologue of receptor activator of NF-kappaB ligand. Journal of Bone and Mineral Research 15 2178-2186. (doi:10.1359/jbmr.2000.15.11.2178)

Yamamoto A, Miyazaki T, Kadono Y, Takayanagi H, Miura T, Nishina H, Katada T, Wakabayashi K, Oda H, Nakamura K et al. 2002 Possible involvement of IkappaB kinase 2 and MKK7 in osteoclastogenesis induced by receptor activator of nuclear factor kappaB ligand. Journal of Bone and Mineral Research 17 612-621. (doi:10.1359/jbmr. 2002.17.4.612)

Received in final form 6 March 2012

Accepted 3 April 2012

Made available online as an Accepted Preprint 3 April 2012 